\title{
Ecological assessment and fitness variation of Elymus farctus (Viv.) Runemark populations in the Mediterranean coast of Egypt
}

\author{
Abdel-Hamid A. Khedr ${ }^{1 *}$, Taha M. El-Katony ${ }^{1}$, Nasser G. Soliman ${ }^{1}$ \\ ${ }^{1}$ Botany Department, Faculty of Science, Damietta University, New Damietta, Egypt.
}

Received: 24 May 2015 / Accepted: 29 September 2015

* Corresponding author: abdelkhedr@du.edu.eg

\begin{abstract}
Coastal sandy habitats of the Mediterranean species E. farctus are vulnerable and ecologically important. The plant distribution is being controlled by several factors at different scales. On a large scale, climate and soil texture play important role in controlling the soil water availability to plants and in separating xerophytic from halic and mesic communities. On a small scale, coastal physiography and soil characteristics are related to floristic composition. Sand mobility and salt spray deposition are important factors in the distribution of the pioneer species on sand dunes. A data set of 26 stands of E. farctus community along the Mediterranean coast of Egypt was analyzed using TWINSPAN classification and DCA, CCA ordination. Four vegetation groups (A-D) are produced with Ammophila arenaria (A), Elymus farctus, Devera tortuosa (B), Alhagi graecorum, Cyperus capitatus (C) and Inula crithmoides, Sencio desfontenii (D), as indicator species of these groups, respectively. Results of ordination indicate that performance of E. farctus is correlated along gradients of calcium carbonates, sodium and potassium content in the soil.

Plant traits (leaf area/shoot length; and reproductive number/shoot length) can be used to assess E. farctus population success. Both the population and community characters, and the soil properties, suggest that the preservation of suitable habitats seems to be important requisites for conservation of E. farctus in the Mediterranean coast of Egypt.
\end{abstract}

Keywords: endangered species, fitness, Mediterranean, multivariate analysis, psammophytes, sand dunes.

\section{Introduction}

The main habitats of the Mediterranean coast of Egypt include sand dunes and salt marshes. The sand dune communities are characterized by a limited number of species as only specialized plants can grow in this habitat (psammophytes). Psammophytes have highly specialized growth form and many have the ability to elongate vertically on burial with sand (Girgis,1973; Zahran et al., 1996; Shaltout and Al-Sodany, 2008).

Elymus is a Mediterranean species (Tackholm, 1974, Boulos, 2005). It is a pioneer of a sand dune with dominant growth form on both mobile and fixed dunes of the Mediterranean coast of Egypt 
(Batanouny 1999, 2006). Recently the coastal area has been traditionally seen as a place for socioeconomic development. During the last century, those coastal dunes have been almost destroyed or profoundly disturbed by logging, urban development and cultivation (Batanouny, 1999). Nowadays, the populations of E. farctus appear in isolated stands of different extension. Large populations still survive in natural or seminatural situations within protected areas, but others have no legal protection.

The protection of coastal dunes is a priority because of the high natural values, recreation, sand stabilization, and their vulnerability (Batanouny, 1999). In addition to the high landscape values, coastal dunes are important because they harbor several endangered plant species (Boulos, 2009), such as Pancratium maritimum and Zygophyllum aegyptium. The fruiting individuals are an important food source for wild animals such as turtles, foxes, birds and rabbits (Khalil and Shaltout (2006). In spite of their ecological value, dune plants in the Mediterranean coast of Egypt are poorly known, and most of the references to studies of this vegetation are about their distribution and economic potentialities (Zahran et al., 1996, Batanouny, 1999). In addition, there is a lack of information about their ecology as a basis for future restoration plans. Elymus has been considered resistant to salt and sand-laden marine winds (Rozema et al.,1985; Sykes and Wilson, 1988), related to a stabilized stage of the dunes (Ciccarelli, 2015), and linked to competition displacement or substrate requirements (Harris and Davy, 1988).

In this study, we analyzed the community and population structure of $E$. farctus along the Mediterranean coast of Egypt, its ecology and biological status, as a basis for future research and management practices. First, the environmental factors conditioning differences in plant composition of Elymus communities along the Mediterranean coast of Egypt were analysed. Second, data about the biological status, which include population fitness within the different Elymus populations, were recorded. Finally, their implications for Elymus conservation are discussed.

\section{Materials and methods}

\section{Study area:}

The Mediterranean coast of Egypt extends for 970 $\mathrm{km}$ from Sallum eastward to Rafah in three sections (Figure 1): the western coast $(550 \mathrm{~km})$, the middle (deltaic) coast $(180 \mathrm{~km})$ and the eastern (Sinai) coast (240 km) (Zahran and Willis, 1992). Two main earth surface processes dominate in the study area: the coastal processes and the aeolian processes. The former produce a variety of coastal landforms such as beaches, wetlands, and salt marshes, whereas the latter produce various types of sand dunes.

The climate of the study area ranges from arid to semi-arid reflecting the regional climate of the Mediterranean coast. Site elevation ranged from $2.00 \mathrm{~m}$ to $25.00 \mathrm{~m}$ a.s.l).

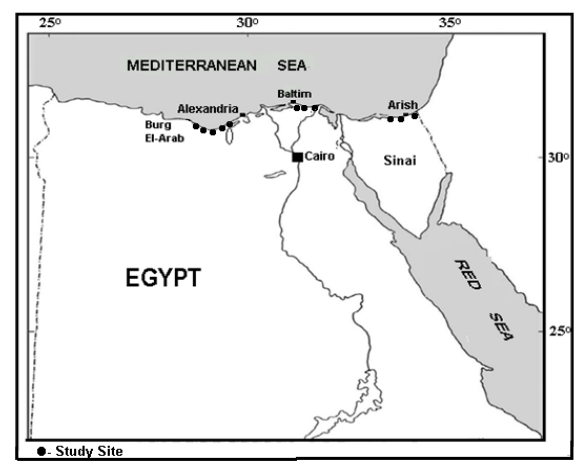

Fig. 1 Study sites of Elymus farctus in the Mediterranean coast of Egypt.

\section{Population analysis}

Ten tillers were randomly collected from 26 populations, and trait analysis was undertaken on the fresh plants. Leaf area was measured for each plant using the method of Ali et al. (1999). Leaf area measurements are known to be a good surrogate for the photosynthetic success of plants, and hence the resources available to be allocated to the progeny. The number of reproductive structures was also recorded, to represent the reproductive success of the individuals.

Elymus farctus fitness can be assessed using the trait measurements (leaf area/shoot length) $\mathrm{x}$ (reproductive number/shoot length).

All the potential sites were surveyed during 2014. Information on coastal physiography, land use, and associated species were recorded. Plant traits have often been used to look at phenotypic and genotypic effect on plant fitness. The ideal fitness measure might include seed production, probability of survival to adulthood and reproductive number of those individuals that survived to adulthood (Dudash, 1990). A method for assessing $E$. farctus success is required to assist a monitoring program aimed at identifying 
at-risk sites, to prioritize action to prevent further deteriorations. Species abundance is often used to determine the success of a species at a particular site.

\section{Vegetation analysis}

An extensive field sampling program was carried out during the period from December 2013 to October 2014, in the sand dunes of the Mediterranean coast of Egypt. Twenty six stands (5m x $5 \mathrm{~m}$ each) were selected in a sandy dune to present the investigated plant species. In each stand the vegetation was analyzed quantitatively. Estimates of relative cover (RC) were obtained by applying the line intercept method using ten parallel lines distributed randomly across the stand (EL-Ghareeb and Abdel-Razik,1984). The lengths of intercept for each perennial species in the sand were then summed up and expressed as a relative value of the total length of all lines. Plant specimens were collected, identified and preserved in the Herbarium of the Faculty of Science, Damietta University. Species identification and floristic categories were according to Boulos $(1995,2005)$.

\section{Soil analysis:}

Three soil samples $(0-10 \mathrm{~cm}$ in depth) were collected within each stand and mixed to form a composite sample, air-dried, passed through a $2 \mathrm{~mm}$ sieve, and packed in paper bags ready for analysis. Soil texture and moisture content determined following the procedures of the United States Salinity Laboratory Staff (Anon, 1954; Jackson, 1962). Soil salinity (EC) was determined in 1:5 soil water extract using an electric conductivity meter (model 35). Soil reaction $(\mathrm{pH})$ was measured using Beckman Bench type $\mathrm{pH}$ meter (mode 5995). Calcium carbonate content was determined following the procedures of Jackson (1962). Oxidizable organic carbon was determined using the Walkely and Black rapid titration method (Black, 1965). Chlorides were determined by direct titration against the Siver nitrate solution using $5 \%$ potassium chromate as an indicator by Jackson (1962). Sodium, potassium and calcium were determined using flame photometer according to Allen et al., (1974).

\section{Data analysis}

The vegetation data were classified using two-way indicator species analysis technique
(TWINSPAN) (Hill, 1979). TWINSPAN was used to classify the entire data set of 26 vegetation plots and 45 plant species. Default options were applied, except for the cut levels (4 cut levels were chosen). The vegetation groups were identified on the basis of their indicator species. The major environmental gradient controlling the composition was identified using canonical correspondence analysis (CCA) ordination (ter Braak, 1987). The difference of values of edaphic variables between the various vegetation groups was tested statistically with the Tukey's studentized test of the unequal means. These analyses were conducted with SPSS 16.0 (SPSS, Chicago, IL, USA).

\section{Results}

Elymus farctus is a perennial grass growing on newly-formed and high dunes which is affected by salt spray in the Mediterranean coast of Egypt. Twenty six stands representing its distribution range are studied.

\section{a-Species classification}

The classification of vegetation data distinguished 4 groups (Table $1 \&$ Figure 2):

Group A: 4 stands on the stabilized siliceous dunes are dominated by Tamarix aphylla. The indicator species is Ammophila arenaria.

Group B: 6 stands on the stabilized calcareous dunes are dominated by Elymus farctus and Devera tortuosa.

Group C: 5 stands on the mobile dunes are indicated by Cyperus capitatus and Alhagi graecorum.

Group D: 11 stands are indicated by Inula crithmoides and Sencio desfontenii on the newlyformed dunes.

\section{$b$-Variations in environmental factors}

Table 2 presents the mean and standard deviation of some soil variables measured for each of the identified vegetation groups. It is clear that Salinity is not important factor in the distribution of E. farctus (not significant). The most important factors responsible for the distribution of $E$. farctus are calcium carbonate, sodium and calcium $\mathrm{P}<0.001$ ). Soil $\mathrm{pH}$, organic carbon, soil moisture, potassium, silt and sand are important factors which are significantly different among vegetation groups $(\mathrm{P}<0.05)$. 
Table 1. Relative cover values of plant species recorded in the four vegetation groups dominated or co-dominated by E. farctus in the Mediterranean coast of Egypt.

\begin{tabular}{|c|c|c|c|c|}
\hline \multirow[b]{2}{*}{ Species } & \multicolumn{4}{|c|}{ Vegetation Groups } \\
\hline & A & \multirow{2}{*}{$\begin{array}{c}\text { B } \\
0.00\end{array}$} & \multirow{2}{*}{$\frac{\mathbf{C}}{0.00}$} & D \\
\hline Acacia saligna & 2.50 & & & 0.00 \\
\hline Alhagi graecorum & 0.00 & 0.00 & 23.0 & 0.00 \\
\hline Ammophila arenaria & 5.21 & 30.87 & 0.00 & 0.00 \\
\hline $\begin{array}{l}\text { Artemisia monosperma } \\
\text { Arthrocnemum }\end{array}$ & \multicolumn{3}{|c|}{ Arthrocnemum } & 0.00 \\
\hline macrostachyum & 0.00 & 0.00 & 0.00 & 15.41 \\
\hline Asparagus stipularis & 5.19 & 0.00 & 0.00 & 0.00 \\
\hline Atractylis carduus & 0.00 & 0.00 & 0.00 & 4.12 \\
\hline Cakile maritima & 0.00 & 1.47 & 0.00 & 3.00 \\
\hline Colligonum comosum & 0.00 & 0.00 & 0.00 & 14.3 \\
\hline Curcinella maritima & 0.00 & 17.78 & 0.00 & 0.00 \\
\hline Cynodon dactylon & 0.00 & 0.00 & 0.00 & 3.45 \\
\hline Cynanchum acutum & 0.00 & 0.00 & 18.75 & 15.0 \\
\hline Cyperus capitatus & 0.00 & 0.00 & 16.8 & 0.00 \\
\hline Devera tortuosa & 0.00 & 5.33 & 0.00 & 0.00 \\
\hline Echinops spinosissmus & 6.71 & 15.43 & 0.00 & 0.00 \\
\hline Elymus farctus & 5.79 & 22.28 & 58.0 & 18.89 \\
\hline Euphorbia paralias & 0.00 & 8.42 & 2.00 & 0.00 \\
\hline \multicolumn{5}{|l|}{ Halocnemum } \\
\hline strobilaceum & 0.00 & 0.00 & 0.00 & 5.26 \\
\hline Inula crithmoides & 0.00 & 0.00 & 0.00 & 13.78 \\
\hline Juncus rigidus & 0.00 & 0.00 & 0.00 & 2.58 \\
\hline Launaea capitata & 0.00 & 0.00 & 17.00 & 11.6 \\
\hline Lygeum spartum & 0.00 & 14.89 & 0.00 & 0.00 \\
\hline Lotus argentus & 0.00 & 6.66 & 4.16 & 0.00 \\
\hline Lycium europaeum & 3.22 & 12.5 & 0.00 & 0.00 \\
\hline Ononis vaginalis & 0.00 & 40.6 & 0.00 & 0.00 \\
\hline Othanths maritimus & 0.00 & 13.88 & 0.00 & 0.00 \\
\hline Phragmites australis & 0.00 & 0.00 & 2.87 & 17.43 \\
\hline Plantago ovata & 0.00 & 0.00 & 4.10 & 0.00 \\
\hline Retama reatam & 0.00 & 21.33 & 0.00 & 0.00 \\
\hline Rumex pictus & 0.00 & 0.00 & 0.00 & 7.02 \\
\hline Salsola kali & 0.00 & 0.00 & 0.00 & 8.50 \\
\hline Scorzonera alexandrina & 0.00 & 5.88 & 0.00 & 0.00 \\
\hline Senecio desfontenii & 0.00 & 0.00 & 0.00 & 15.0 \\
\hline Silene succulenta & 4.10 & 0.00 & 0.00 & 0.00 \\
\hline Stipagrotis lanata & 0.00 & 0.00 & 0.00 & 9.00 \\
\hline Stipagrotis scoparia & 8.78 & 0.00 & 0.00 & 33.0 \\
\hline Suaeda vera & 0.00 & 0.00 & 0.00 & 33.62 \\
\hline Tamarix aphylla & 31.73 & 0.00 & 0.00 & 0.00 \\
\hline Tamarix nilotica & 0.00 & 0.00 & 0.00 & 3.60 \\
\hline Thymealea hirsuta & 0.00 & 20.00 & 0.00 & 0.00 \\
\hline Zygophyllum aegyptium & 0.00 & 11.70 & 0.00 & 5.17 \\
\hline \multicolumn{5}{|c|}{26 Stand } \\
\hline 10 & & & \multicolumn{2}{|l|}{16} \\
\hline & & 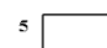 & & 11 \\
\hline$\underset{\text { Amm. are. }}{\downarrow}$ & & $\begin{array}{l}\text { Alh. gro. } \\
\text { Cyp. cap. }\end{array}$ & & aef. \\
\hline Stands $\rightarrow 23,24,25,26$ & 20,21 & $8,10,12,13,22$ & $1,2,3,4,5,5,6$ & $7,9,11,14,15$ \\
\hline Groups $\rightarrow \overleftrightarrow{A}$ & & 4 & & \\
\hline
\end{tabular}

Fig. 2 TWINSPAN dendrogram of the 26 stands based on the cover values of 41 species representing the different habitats of Elymus farctus in the Mediterranean coast of Egypt. Indicator species are abbreviated to the first letter of the genus and the first three letters of species names respectively. For full names of species see Table 1 .
Table 2. Means, standard deviation ( \pm ) and one-way ANOVA between vegetation groups for 12 edaphic variables.

\begin{tabular}{|c|c|c|c|c|c|}
\hline & $\begin{array}{c}\text { A } \\
(n=4)\end{array}$ & $\begin{array}{c}\mathrm{B} \\
(\mathrm{n}=6)\end{array}$ & $\begin{array}{c}\mathrm{C} \\
(\mathrm{n}=5)\end{array}$ & $\begin{array}{c}\mathrm{D} \\
(\mathrm{n}=11)\end{array}$ & $F$ value \\
\hline \multirow[t]{2}{*}{$\mathrm{EC}(\mu \mathrm{S} / \mathrm{cm})$} & 515.00 & 497.66 & 432.80 & 480.81 & $1.36 \mathrm{~ns}$ \\
\hline & \pm 284.42 & \pm 275.15 & \pm 173.03 & \pm 315.34 & \\
\hline \multirow[t]{2}{*}{$\mathrm{pH}$} & 7.86 & 7.76 & 6.70 & 7.28 & $5.78 *$ \\
\hline & \pm 0.53 & \pm 0.24 & \pm 0.53 & \pm 0.55 & \\
\hline \multirow[t]{2}{*}{$\mathrm{OC}(\%)$} & 0.29 & 0.06 & 0.14 & 0.13 & $7.57 *$ \\
\hline & \pm 0.07 & \pm 0.03 & \pm 0.03 & \pm 0.11 & \\
\hline \multirow[t]{2}{*}{$\mathrm{CaCO}_{3}(\%)$} & 15.97 & 96.67 & 4.70 & 5.31 & $952.56 * * *$ \\
\hline & \pm 2.33 & \pm 0.41 & \pm 1.95 & \pm 1.91 & \\
\hline \multirow[t]{2}{*}{$\mathrm{Cl}^{-}(\%)$} & 0.98 & 0.06 & 0.02 & 0.07 & $18.52 * *$ \\
\hline & \pm 0.57 & \pm 0.04 & \pm 0.01 & \pm 0.13 & \\
\hline \multirow[t]{2}{*}{$\operatorname{MC}(\%)$} & 1.06 & 0.43 & 0.08 & 0.45 & $5.08 *$ \\
\hline & \pm 0.38 & \pm 0.13 & \pm 0.03 & \pm 0.51 & \\
\hline \multirow[t]{2}{*}{$\mathrm{Na}^{+}$} & 2.33 & 0.15 & 0.39 & 0.43 & $111.56^{* * *}$ \\
\hline & \pm 0.48 & \pm 0.06 & \pm 0.11 & \pm 0.11 & \\
\hline \multirow[t]{2}{*}{$\mathrm{K}^{+}$} & 5.1 & 1.56 & 1.72 & 1.74 & $17.51 *$ \\
\hline & \pm 1.49 & \pm 0.58 & \pm 0.99 & \pm 0.65 & \\
\hline \multirow[t]{2}{*}{$\mathrm{Ca}^{2+}$} & 13.32 & 47.67 & 2.15 & 1.78 & $230.65 * * *$ \\
\hline & \pm 5.046 & \pm 6.45 & \pm 0.99 & \pm 0.51 & \\
\hline \multirow[t]{2}{*}{ Sand $(\%)$} & 93.03 & 89.96 & 85.84 & 83.84 & $6.85 *$ \\
\hline & \pm 1.29 & \pm 3.26 & \pm 1.55 & \pm 5.18 & \\
\hline \multirow[t]{2}{*}{ Silt (\%) } & 3.49 & 5.40 & 10.80 & 11.26 & $8.46^{*}$ \\
\hline & \pm 0.36 & \pm 1.58 & \pm 1.96 & \pm 4.58 & \\
\hline \multirow[t]{2}{*}{ Clay (\%) } & 3.98 & 4.13 & 3.94 & 4.19 & $1.55 \mathrm{~ns}$ \\
\hline & \pm 0.66 & \pm 1.97 & \pm 0.82 & \pm 1.57 & \\
\hline
\end{tabular}

\section{c-Species-environment relationship}

The ordination diagram produced by CCA is shown in Fig. 3. The position of E. farctus and associated species along the gradient of 12 soil variables was clear. The diagram showed that calcium carbonates, calcium, sodium and sand are the most important factors related to the distribution of E. farctus in the study sites. The distribution of $E$. farctus was concentrated at the end of the lower gradient of calcium carbonates, calcium and sodium, and on the intermediate gradient of sand. The psammophytic species like Thymelaea hirsuta, Ononis vaginalis and Zygophyllum aegyptium showed an opposite trend of distribution to that of E. farctus. However, the pioneers of newly-formed sandy habitat e.g. Salsola kali and Cakile maritima showed similar trend of distribution to that of E. farctus.

\section{d-Fitness}

Figure 4 shows the log fitness for each site surveyed where ten tillers could be assessed. One site at Gamsa, 7 sites at Baltim, and three sites at North Sinai have a $\log$ fitness value below one, these sites are those perceived to be at risk. It was also observed that $E$. farctus did not grow in great 
abundance at these sites. North Sinai despite having relatively leafy plants only had a few grains on each tiller. This suggests that the population size will be smaller next year.

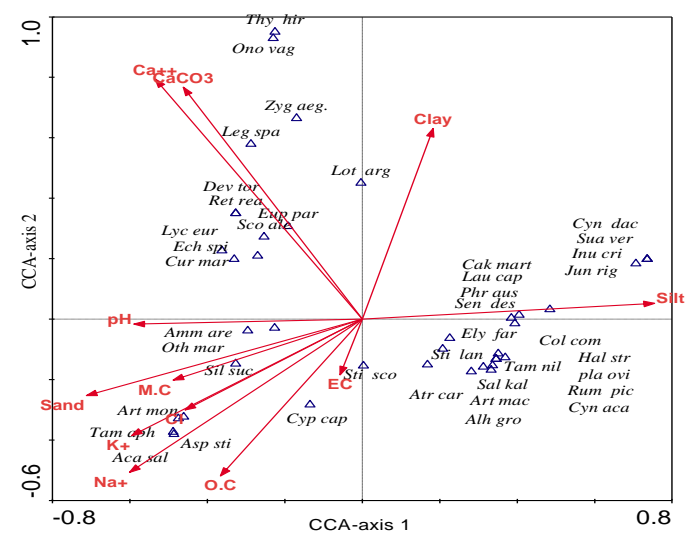

Fig.3. Canonical Correspondence Analysis (CCA) ordination diagram with 12 soil factors represented by arrows and plant species represented by points. Species names are abbreviated to the first three letters of genus and species names respectively. For complete species names see Table (1).

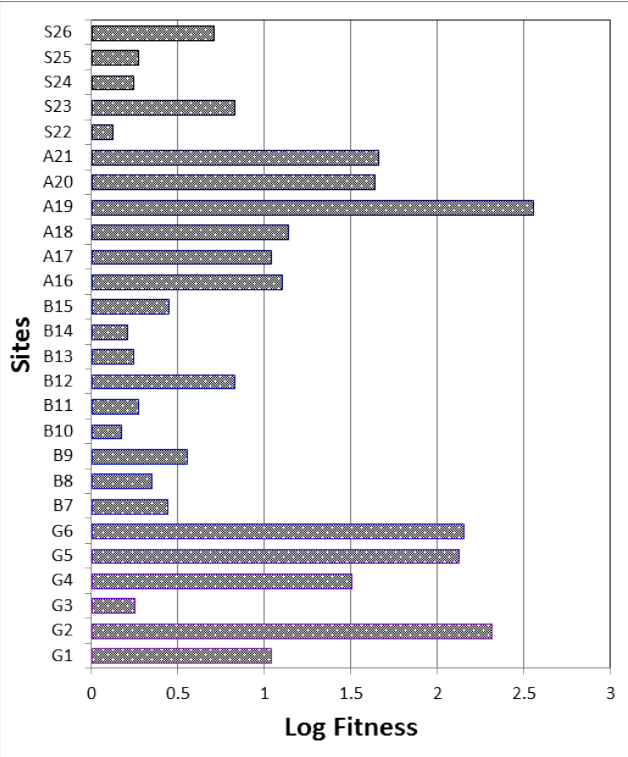

Fig 4. The observed mean log fitness (leaf area/shoot length $\mathrm{x}$ reproductive number/shoot length) at all the study sites. Sites (1-6 Gamsa), (7-15 Baltim), (16-21 West Alexandria) and (22-26 North Sinai).

\section{Discussion}

Coastal dunes form one of the major habitats of the Mediterranean coast of Egypt. In all stages of dune formation, Elymus farctus is among the growing psammophytes, although its abundance is distinctly lower on stable than on active dunes. On salt marshes, this species becomes less important and the vegetation is co-dominant by a group of equally abundant halophytic species. Many of the species common on the dunes are deeply rooted. Elymus farctus is recorded to dominate on fore dunes and early stages of dune formation which are less stable and their soil loose, poor in the nutrients and probably affected by salt marsh. It has considerable resistance to salinity and considered as a facultative halophyte (Barbour,1970; Rozema et al.,1985; Del Vecchio et al., 2015). Elymus farctus has the ability of sand fixation and of furnishing a less hostile habitat for other species, e.g. Echinops spinosissimus, Artemisia momsperma, Alhagi graecorum, Thymelaea hisruta and Silene succutenta which become more and more common until they dominate the stable dunes. This species grows on dunes and open sands on the Atlantic coast of Europe and in northern Africa, where it forms part of the plant community on upper beaches, embryonic dunes and fore dunes. It is a pioneer species: highly adapted to sand burial and hardy to adverse seashore conditions. It plays a part in the formation of mounds of sand and embryonic dunes. It is considered as the pioneer of psammosere in the Mediterranean dunes in Egypt (El-Ghareeb and Rezk, 1989).

The relationships between the variability of plant communities in response to the variability soil characteristics have been well established by many previous studies such as (Shaltout, 1983; Zahran et al., 1990; Khedr, 1993). The present study showed that calcium carbonate, sodium and calcium are among most important factors responsible for the distribution of E. farctus in the Mediterranean coast of Egypt.

Because of the rapid expansion of human activities, many species occupy few habitats for existence, while others become endangered or extinct (Khedr, 2007).

The instability of sand dunes is a crucial factor affecting the growth and survival of dune plants due to intensive human activities and habitat alteration, considerable changes in coastal vegetation. The deterioration of sand dune plants is obvious (Batanouny 1999, 2006; Malavasi et al., 2014) which decreases plant cover and species diversity. For these reasons, it is important to document these changes for possible evaluation of negative effects on plants.

The native dune plants (Psammophytes) are capable not only of maintaining dune stability, but can also colonize patches of bare sand and quickly grow down an eroded dune face to help build up 
and restore the dune profile (Labuz and Grunewald, 2007; Xu et al., 2015).

Floristic changes in fore dunes, dominated by rhizomatous grasses such as Ammophila arenaria and Elymus farctus, are particularly important because they are likely the most important habitats on sandy coasts due to their role in preventing coastal erosion and maintaining and enhancing the natural, cultural and amenity values of beaches (Drius et al., 2013; Stoll et al., 2015).

As a result of human activities, various disturbances have occurred in the landscapes habitats through the last decades. These disturbances are represented by: habitat destruction which occurs as a result of the removal of the original habitat such as the removal of sand dunes for construction and agriculture activities; habitat degradation which occurs as a result of reclamation activities in the study area where soil of the original habitat undergoes intensive reclamation activities; habitat creation that occurs in association of various human activities such as fish farms and irrigation and drainage canals; and habitat fragmentation which occurs as a result of dissecting landscapes by road and drainage/irrigation networks.

\section{References}

Ali, M.M., K.J. Murphy and V.J. Abernethy, 1999. Macrophyte functional variables versus species assemblages as predictors of trophic status in flowing waters. Hydrobiologia 415: 131-138.

Allen S.E., Grimshaw H.M., Parkinson J.A. and Quarnby C. 1974. Chemical analysis of ecological materials (Oxford: Blackwell)

Anon 1954. Diagnosis and Improvement of SalineAlkaline Soils. U.S. Salinity Laboratory Staff, U.S. Agriculture Handbook No. 60., Washington, DC.

Barbour, M.G. 1970. Is any angiosperm an obligate halophyte?. American midland naturalist, 105-120.

Batanouny, K.H.1999. The Mediterranean Coastal Dunes in Egypt: An Endangered Landscape. J. of Estuarine, Coastal and Shelf Science, 49: 3-9.

Batanouny, K.H. 2006. Adaptation of Desert Organisms "Plants of the Deserts of Middle East", II series. Springer-Verlag, Berllin Heidelberg New York.

Black C.A. 1965. Methods of Soil Analysis. Part 2. In: Black C.A. (ed.), Agronomy No. 9. American Society of Agronomy, Madison, Wisconsin, pp. $771-1572$

Boulos L. 1995. Flora of Egypt, a Checklist. Al Hadara Publishing, Cairo
Boulos L. 1999. Flora of Egypt, AzollaceaeOxalidaceae. 1st edn. Vol. 1. Al Hadara Publishing, Cairo.

Boulos, L. (2005). Flora of Egypt (Vol. 4). Al Hadara Publishing.

Ciccarelli, D. 2015. Mediterranean coastal dune vegetation: Are disturbance and stress the key selective forces that drive the psammophilous succession?. Estuarine, Coastal and Shelf Science (In Press).

Del Vecchio S., Prisco I, Acosta A.T.R., Stanisci A. 2015. Changes in plant species composition of coastal dune habitats over a 20 -year period. AoB Plants 7: 1-10.

Drius M., Malavasi M., Acosta A.T.R., Ricotta C., Carranza M.L. 2013. Boundary-based analysis for the assessment of coastal dune landscape integrity over time. Applied Geography 45:41-48.

Dudash, M.R. 1990. Relative fitness of self and outcrossed progeny in a self-compatible, protandrous species, Sabatia angularis L. (Gentianaceae): a comparison in three environments. Evolution 44: 1129-1139.

El-Ghareeb, R. and Abdel Razik, M.(1984). A study on the phytosociology of the wadis southern Sinai. Bull. Fac. Sci. Alex. Univ.,24(4):213-234.a

El-Ghareeb, R. and Rezk, R.M. 1989. A preliminary study on the vegetation of the coastal land at Bousseli (Egypt). J. Univ. Kuwait (Sci.) 16: 115 127.

Girgis,W.A..1973. Phytosociological studies on the vegetation of Ras El- Hikma Marsa Matrouh coastal plain. Egyptian J. Bot., 16:393-409.

Harris, D. and Davy, A.J. 1988. Carbon and nutrient allocation in Elymus farctus seedlings after burial with sand. Annals of Botany, 61(2), 147-157.

Hill, M.O., 1979. TWINSPAN-a FORTRAN Program for Arranging Multivariate Data in an Ordered Two Way Table by Classification of Individual and Attributes Ecology and Systematics. Cornell University, Ithaca, New York, pp: 90.

Jackson M.L. 1962. Soil Chemical Analysis. Constable and Co Ltd, London.

Khalil, M.T. and Shaltout, K.H. 2006. Lake Bardawil and Zaranik Protected Area, Publi. Biodiversity Unit No. 15.

Khedr, A.A. 1993. Ecological studies on some halophytes, xerophytes and psammophytes with particular reference to their environmental adaptation. Ph.D. Thesis, Faculty of Science, Mansoura University Mansoura, Egypt.

Khedr, A.A. 2007. The Ecological Status of the Endangered Spiny Juniper, Juniperus oxycedrus ssp. macrocarpa (Sibth.\&Sm.) Ball. in Jebel AlAkhdar, Libya. El-Minia Science Bull. 18(1):51-68. 
Labuz, T.A., and Grunewald, R. (2007). Studies on vegetation cover of the youngest dunes of the Swina Gate Barrier (western Polish coast). Journal of Coastal Research, 160-172.

Malavasi M., Santoro R., Cutini M., Acosta A.T.R., Carranza M.L. 2014. The impact of human pressure on landscape patterns and plant species richness in Mediterranean coastal dunes. Plant Biosystems doi: 10.1080 /11263504. 2014.913730.

Rozema, J., Bijwaard, P., Prast, G., and Broekman, R. (1985). Ecophysiological adaptations of coastal halophytes from foredunes and salt marshes. In Ecology of coastal vegetation (pp. 499-520). Springer Netherlands.

Shaltout, K.H. 1983. An Ecological Study of Thymelaea hirsuta (L.). Endl. In Egypt. PhD Thesis, Fac. Sci., Tanta Univ., Egypt.

Shaltout K.H. and Al-Sodany Y.M. 2008.Vegetation analysis of Burullus Wetland: a RAMSAR site in Egypt, Wetlands Ecology and Management, 16: 421-439

Stoll S., Frenzel M., Burkhard B., Adamescu M., Augustaitis A., Baeßler C., Bonet F.J., Carranza M.L., Cazacu C., Cosor G.L., Di'az-Delgado R,Grandin U., Haase P., Hamalainen H., Loke R., Muller J., Stanisci A., Staszewski T., Muller F. 2015. assessment of ecosystem integrity and service gradients across Europe using the LTER Europe network. Ecological Modelling 295:75-87.

Sykes, M.T. and Wilson, J.B. 1988. An experimental investigation into the response of some New Zealand sand dune species to salt spray. Annals of Botany, 62(2), 159-166.

Täckholm, V. 1974. Students' Flora of Egypt.2nd Edition. Cairo Univ. 888 PP.

ter Braak, C.J.F. 1987. The vegetation-environment relationships by Canonical correspondence analysis. Vegtatio, 69:69-77

Xu, Z., Mason, J. A., \& Lu, H. 2015. Vegetated dune morphodynamics during recent stabilization of the $\mathrm{Mu}$ Us dune field, north-central China. Geomorphology, 228, 486-503.

Zahran, M.A. and Willis, A.J. 1992. The vegetation of Egypt. Chapman and Hall, London, 424 PP.

Zahran, M.A., El-Demerdash, M.A. and Mashaly, I.A. 1990. Vegetation types of the deltaic Mediterranean coast of Egypt and their environment. J. Veg. Sci., 1: 305-310.

Zahran, M.A., Murphy, K.J. and Khedr, A.A.1996. On the Ecology of some Halophytes and Psammophytes in the Mediterranean coast of Egypt. Verhandlungen der Gesellschaft für Okologie, 25: 133-146.

عنوان البحث: التقييم البيئي والتباين المظهري لعثيرة نبات الجازوف على ساحل البحر الأبيض عبدالحميد عبد الفتاح خضر ، طه سليمان القاطوني، ناصر جادادالله سليمان

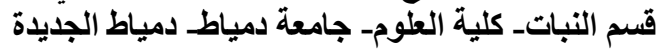

يعتبر نبات الجازوف من النباتات الهامه بيئيا على ساحل البحر المتوسطو يتحكم في توزيعه عدة عوامل

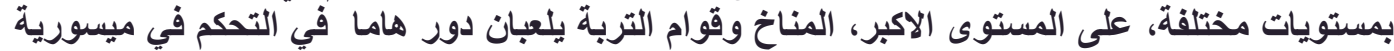

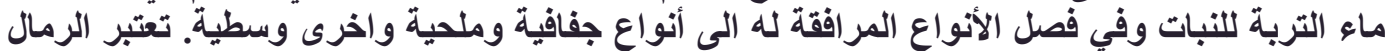

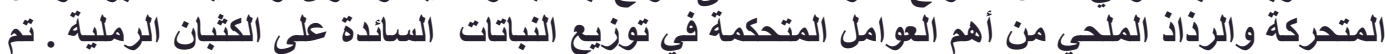

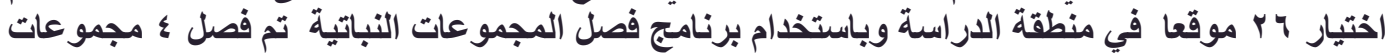

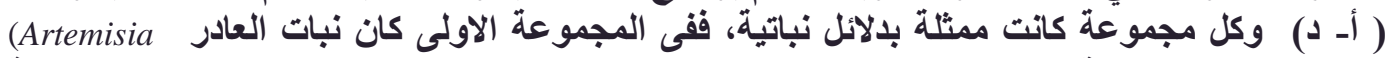
monosperma)

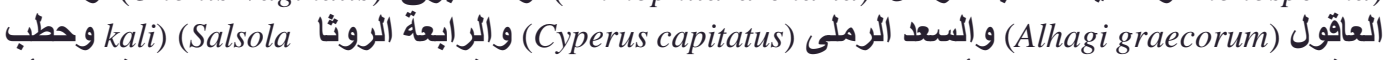

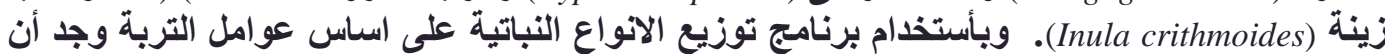

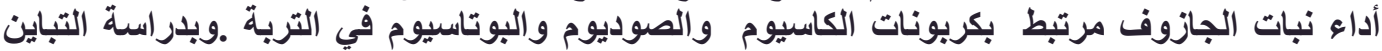

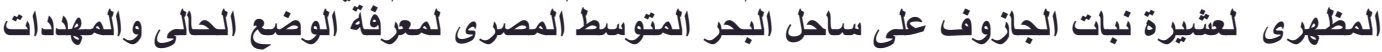

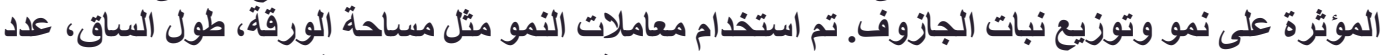

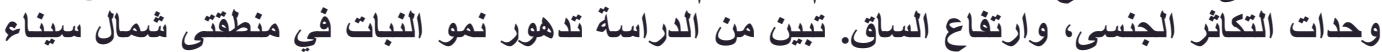

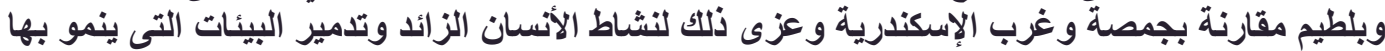

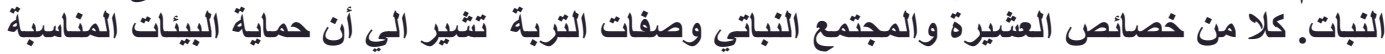
تبدو كمنطلبات هامة للحفاظ على نبات الجازوف فئي ساحل النب البحر المتوسط. 